POLITICAL CHALLENGES FOR EDUCATION AND DEMOCRACY IN LATIN AMERICA ${ }^{1}$

\title{
OS DESAFIOS POLÍTICOS PARA A EDUCAÇÃO E DEMOCRACIA NA AMÉRICA LATINA
}

\author{
LOS DESAFÍOS POLÍTICOS PARA LA EDUCACIÓN Y LA DEMOCRACIA EN \\ AMÉRICA LATINA
}

\author{
Fabiano Antonio dos SANTOS ${ }^{2}$ \\ Silvia MARTINEZ ${ }^{3}$ \\ João Batista ZANARDINI ${ }^{4}$
}

\begin{abstract}
We highlight in this dossier, among the issues that bring Latin American countries together, the political challenges surrounding the provision of education and the strengthening of democracy, and the reflection of the adoption of political measures that lead to a high percentage of indigence and poverty in most countries of the region. The politicaleconomic agenda was built on the tension from two different perspectives, the implementation of neoliberal and conservative policies, bumps into collective organization to resist exclusion and propose different social projects. It is in this context, increasingly fierce in terms of conflicts and struggles, that reflections are needed on various aspects that shape our reality, such as education and the strengthening of democracy. It is along these lines that we are interested in the connection between education and other areas of social life, such as: education and work, education and citizenship, education and teaching work, education and evaluation, education and international organizations; among others. This is how we present reflections on different perspectives that problematize some aspects of educational policies and practices in the region. We invite you to get to know, debate and exchange experiences about the reality through the contributions on education and its alternatives, criticism and theoretical reflections present in this Dossier and that they help to build more democracy through education and social justice.
\end{abstract}

KEYWORDS: Democracy. Education. Citizenship. Social justice. Political challenges.

\footnotetext{
${ }^{1}$ Translated by Alexander Vinícius Leite da Silva

${ }^{2}$ Federal University of Mato Grosso do Sul (UFMS), Corumbá - MS - Brazil. Professor of the Pedagogy course and of the Postgraduate Program in Education (PPGE/CPAN). Doctorate in Education (UFSC). ORCID: https://orcid.org/0000-0002-7703-8520. E-mail: fabiano.santos@ufms.br

3 Patagonian Institute of Humanities and Social Sciences Studies (IPEHCS-CONICET-UNCo); Faculty of Education Sciences, National University of Comahue (FACE-UNCo), Neuquén - Argentina. Regular Adjunct Professor. Didactic Department. ORCID: https://orcid.org/0000-0001-8473-9934. E-mail: silviamarcelamartinez@gmail.com

${ }^{4}$ Western Paraná State University (UNIOESTE), Cascavel - PR - Brazil. Professor of the Pedagogy Course. Doctorate student in Education. (UFSC). ORCID: https://orcid.org/0000-0002-1514-6489. E-mail: j.zanardini@uol.com.br
} 
RESUMO: Destacamos neste dossiê, entre as questões que congregam os países latino americanos, os desafios políticos em torno da oferta de educação e do fortalecimento da democracia e o reflexo da adoção de medidas políticas que leva a uma alta porcentagem de indigência e pobreza na maioria dos países da região. A agenda político-econômica foi construída na tensão de duas perspectivas diferentes, a implementação de políticas neoliberais e conservadoras, esbarra na organização coletiva para resistir a exclusão e propor diferentes projetos sociais. É nesse contexto, cada vez mais feroz em termos de conflitos e lutas, que são necessárias reflexões sobre vários aspectos que moldam nossa realidade, como é o caso da educação e do fortalecimento da democracia. É nessa linha que nos interessa a relação da educação com outras áreas da vida social, como por exemplo: educação e trabalho, educação e cidadania, educação e trabalho docente, educação e avaliação, educação e organizações internacionais; entre outras. É assim que apresentamos reflexões sobre diferentes perspectivas que problematizam alguns aspectos das politicas $e$ práticas educacionais da região. Convidamos, então, a conhecer, debater e trocar experiências sobre a realidade por meio das contribuições sobre a educação e suas alternativas, críticas e reflexões teóricas presentes neste Dossiê e que as mesmas auxiliem na construção de mais democracia através da educação e da justiça social.

\section{PALAVRAS CHAVE: Democracia. Educação. Cidadania. Justiça Social. Desafios políticos}

RESUMEN: En este dossier, entre los temas que reúnen a los países latinoamericanos, destacamos los retos políticos que rodean la provisión de educación y el fortalecimiento de la democracia y el reflejo de la adopción de medidas políticas que conducen a un alto porcentaje indigencia y pobreza en la mayoría de los países de la región. La agenda política y económica fue construido en dos perspectivas diferentes, la aplicación de políticas neoliberales y conservadores se enfrenta la organización colectiva para resistir y proponer proyectos sociales diferentes. Es en este contexto, cada vez más feroz en términos de conflictos y luchas, que son necesarias reflexiones sobre diversos aspectos que dan forma a nuestra realidad, como la educación y el fortalecimiento de la democracia. Es en esta línea que nos interesa la relación entre educación y otras áreas de la vida social, tales como: educación y trabajo, educación y ciudadanía, educación y enseñanza, educación y evaluación, educación y organizaciones internacionales; entre otras. Así es como presentamos reflexiones sobre diferentes perspectivas que apuntan aspectos de las politicas y prácticas educativas en la región. Invitamos, entonces, a conocer, debatir e intercambiar experiencias sobre la realidad a través de los aportes sobre educación y sus alternativas, críticas y reflexiones teóricas presentes en este Dossier y que ayuden en la construcción de más democracia a través de la educación y la justicia social.

PALABRAS CLAVE: Democracia. Educación. Ciudadanía. Justicia social. Desafios políticos.

Among the most varied issues that bring together the Latin American peoples, the geopolitical issue seems to be one of the most detachable, a fact that has intensified especially since the mid-twentieth century with the challenges facing democracy throughout the region. At the same time, the repressive experiences of decades of dictatorships regulated and 
commanded by North America have placed the region in a very critical position on the world economic scene, but above all they have contributed to making democratic regimes fragile and susceptible to the interests of capitalism in its conservative / neoliberal phase, at least in several countries of the region. Not always in the same way and with the same intensity, in the last 20 years, populist or "new sign" governments have also been formed which, even without abandoning the demands imposed by a globally structured agenda, have adopted social measures of "protection", assistance and extension of rights. Recent history shows the tensions that arise within these models, with a high percentage of indigence and poverty prevailing in most countries in the region. The current scenarios show us that the adoption of these policies, and the insufficiency of these actions to satisfy the needs of the most vulnerable population, are further aggravated by the structural crisis in capital.

In this panorama, the political-economic agenda was built on the tension from two different perspectives: on the one hand, and in a hegemonic way in the region, neoliberal and conservative policies were assumed, relegating to second place, those aimed at adopting measures to improve the life of the population in social fields. On the other hand, in almost all countries there are counterproposals that refer to progressive measures and, therefore, during conflicts, there is a vehement fight in different sectors to their guarantee. Fortunately, the Latin American peoples find in collective organization the driving force to resist exclusionary projects and propose different social projects, challenging the economic policies in force.

It is in this context, increasingly fierce in terms of conflicts and struggles, that reflections on various aspects that shape our reality are needed, such as education, understood here as one of the components of social policies, being questioned, on the one hand, by a permanent criticism of the more liberal or conservative sectors and, on the other, by the needs and demands of the population around the extent of schooling and the complexity of knowledge in dispute that should be contemplated as part of life.

This scenario of conflicts of which education is a part imposes the urgency of exposure and questions about: progressive public policies, conservative policies and their consequences, the existence of organizations in some countries of social movements that unite in the struggle to repel the conservative wave in Latin America, in addition to rescuing the democratic social construction that continues to operate even in hostile contexts. It is along these lines that we are interested in the relationship between education and other areas of social life, such as: education and work, education and citizenship, education and teaching work, education and evaluation, education and international organizations; among others. 
The undeniable crisis of capitalism that lasts more than 30 years affects all countries to a greater or lesser degree, we risk saying that even more so when it comes to peripheral countries such as Latin American ones. This is the topic addressed by Thiago de Jesus Esteves and José dos Santos Souza in the paper "The role of international organisms in the management reform of brazilian education: large-scale educational assessment systems as instruments of the political pedagogy of capital". The authors conclude that much of the inequality of political power and also of wealth of many countries that are not at the financial center of the capitalist system, is directly linked to the adoption of educational policies proposed by international organizations, focusing on what they call the political pedagogy of capital in the regulation of large-scale evaluation instruments. On the other hand, they present studies that relate the national educational policy of several countries to international policy showing from this relationship, meanings and/or purposes that are produced around macro or medium range policies.

For almost the entire Latin American region, there is usually a flow of proposals certified by international organizations and supported by national elites who seek to mitigate the problems generated by the structural crisis in the global economic and financial sector, as well as favor the private sector. So it was, almost without regional exceptions, the dictate surrounding the crisis and the ineffectiveness of national states in providing and guaranteeing their republican roles, putting the majority in an endless process of reforming the state role. The dictate surrounding the assumption of practices that guarantee so controversial sustainable development as a guarantee of participation in the mode of production, which ultimately lacks support, also affects with pungent force.

This subject is dealt with in the paper by Eneida Oto Shiroma and Isaura Monica Souza Zanardini, entitled "State and management of education for sustainable development: capital recommendations expressed in the 2030 agenda", where the authors present the valorization of successful experiences and practices and the monitoring and dissemination of results by the State, as the main factors for the promotion of the so-called sustainable development.

In contrast, the paper "The obscurantist neoliberal common sense and its impacts on brazilian education" authored by: Newton Duarte, Francisco José Carvalho Mazzeu and Elaine Cristina Melo Duarte referenced theoretically in Antonio Gramsci's thought about common sense, it is revisited the problem of how the neoliberal prescription was repeatedly placed as the great panacea capable of resolving all difficulties and promoting a regional start towards the prosperity of their political and also economic systems, for that, the invisible 
hand of the market remains the guideline that not only regulates governmental possibilities , but also the possibilities of civil freedom, in the most varied aspects.

The maintenance of these policies by the states has left a devastating picture in the field linked to the guarantee and attainment of social rights, which leads to the struggle for policies of more generalist scope on the part of subjects or collectivities, in various sectors both for entering the labor market and for so-called citizen learning, in the appropriation of scientific knowledge and more varied knowledge in terms of social justice with regard to differences and diversity.

We believe that the main role played by access to education is to guarantee access to other social rights, since, from the point of view of social justice, it is a question of thinking from the point of view of the possibility of cultural distribution, recognition of differences and real participation in all aspects of society.

In this sense, the study on normative policies in the region is addressed by the paper "The right to school education as a dimension of citizenship in Mercosur", by Kellcia Rezende Souza, Maria Teresa Miceli Kerbauy and Rosalina Dantas da Silva, where they analyze the constitutional order of the member countries (Argentina, Brazil, Paraguay, Uruguay and Venezuela) of the Southern Common Market (Mercosur), regarding the right to education. In this way, they understand that the guarantee of education passes through the conceptions of citizenship and how this can contribute to democracy. The current constitutions of these countries have been studied where they note the absence in the legal instruments that regulate the progress and effectiveness of educational law and, therefore, the conquest of citizenship as an instrument of regional integration.

One of the obstacles to regional integration on the part of Brazil is the ineffectiveness of the internationalization policy. This issue is discussed by Jullie Cristhie da Conceição, Milene Dias Amorim and Giselle Cristina Martins Real in the paper "Student mobility in latin america: reveals of validation of foreign certificates in Brazil". Taking as part of the empiricism the public and restricted data of the Ministry of Education's own information system to manage the processes of recognition and revalidation of foreign diplomas called Carolina Bori Platform, in the period from 2017 to 2019, the authors conclude that: as far as the validation of diplomas is concerned, the perspective that is glimpsed indicates that the private interests linked to commercial interests of private institutions continue to be predominant. And as for student mobilization, it materializes much more in consideration of implicit commercial interests than in the perspective of expanding the Brazilian internationalization policy. 
In the paper "The evaluation programs in the recent government agenda in Argentina: discourses, actions and institutionalities of the policies oriented to the improvement of the quality of education during the management of Cambiemos (20152019)", the authors Lucrecia Rodrigo and Inés Rodríguez Moyano, as the title indicates, analyze qualitatively the national educational evaluation policies within the scope of the movement that they call "conservative restoration in Argentina". They review the structural frameworks of the evaluation programs, that is, the "institutional architecture" of the educational evaluation area, then analyze the orientation of the interventions developed during the years 2015-2019 by the Evaluation Secretariat linked to the National Ministry of Education and some opinions of different actors responsible for the design and implementation of these policies. The authors point out that the process of measuring learning inherent in "conservative restoration" favors evaluation as a control tool, that is, as "privileged management", notably different from the previous educational policy. They conclude by presenting some reflections on the relevance of evaluation policies for the process of expanding the right to education in Argentina.

The concern of this dossier focuses on the theme of social justice and the construction of democracy. Previously, we referred to the idea of social justice based on the concepts of Fraser $(2008)^{5}$, which in a few articles of this Dossier appear revalued based on the knowledge that the school or society promotes in relation to the construction of citizenship. This is the case of the paper "Basic learning in citizenship in chilhood to strengthen democracy: results of a citizen-led assessment in Mexico" by Felipe J. Hevia and Samana Vergara Lope in which the authors show that democracy and the construction of a comprehensive citizenship have little importance in Mexican society. This is "directly related to the problems of the educational system to educate comprehensive citizens". They present the evaluation of 1436 girls, boys and adolescents, emphasizing the importance of teaching a minimum content, which could be dealt with by the school, in order to build citizenship. The data indicate that ideas around citizenship are weak or weaken with age, that is, it is a necessity that education contributes not only to conceptual content, but to a broader knowledge that leads "to the common good and mutual support, and to the generation of skills and abilities for coexistence and participation, such as dialogue, peaceful conflict management and the construction of violence-free spaces".

\footnotetext{
${ }^{5}$ Fraser and Nancy (2008). "La justicia social en la era de la política de identidad: redistribución, reconocimiento y participación". Revista de Trabajo (6), 83-99 (en línia). Available in: http://www.trabajo.gob.ar/downloads/cegiot/08ago-dic_fraser.pdf. Access in: 22 abr. 2020.
} 
What we may call democratic fragility in the Latin American region is felt not only in its broad sense but also in the authoritarian field of building policies independently of the base in which they affect them, but also in the consideration that subjects make about their own condition as citizens and about the validity of democracy in the most general sense, which leads both to the maintenance of authoritarian states dressed as republicans and to individual and collective apassivamento combined with the fragile fabric of regional democracies.

At least two articles deal with the issue of formation and exploitation of teaching work, arguing that there are many challenges encountered in order to break with this nebulous web that involves the living conditions of all workers. Many of these challenges are addressed in the paper "Political, economic and social challenges for the teachers in Latin America" by Fabiano Antonio dos Santos, João Batista Zanardini and Hellen Jaqueline Marques which deal with various themes that constitute challenges for teachers, from initial formation, career, through issues related to the quality of education and the problem of large-scale evaluation, reaching union political participation. The authors conclude that each of these challenges, whether in their specificity or interdependence, produces reactions, struggles, conditioning and possibilities that cross the official field of political proclamations to the forms of confrontation by teachers of the same policy.

In the specific case of the teaching condition, the conditions of formation, employment and maintenance of their careers are severely impaired, culminating in scorching processes of exploitation of their workforce, for which the increase in remote education disguised of education to distance, uberized work leading up to voluntary work.

In the paper "School educational aims and socially-just school: the pedagogical approach to social and cultural diversity", the authors José Carlos Libâneo and Eliane Silva present the clashes surrounding the relationship between educational purposes, cultural diversity, inequality and justice. They center their propositions based on Brazil and some Latin American countries in relation to the social function of education, and argue that, although "socio-political actions and pedagogical actions must be articulated, they do not identify themselves once their nature is different". They conclude with an interesting proposal for a pedagogical approach to diversity in a socially just school from the perspective of teaching geared towards human development.

In this same sense, the paper "Secondary school and work formation in Argentina: policies and knowledge in dispute", the authors Silvia Martínez, Delfina Garino and Natalia Fernández discuss the relationship between education and work from three experiences in secondary technical schools in Argentina. They show, through the training devices for work, a 
deep debate about the educational purposes and, with it, the knowledge that is transmitted and the conceptions of work that they promote, as well as the tension between what happens in schools and in the regulations. policies. They discover, in political terms, that teaching proposals can promote the construction of a more just and democratic world or deepen social inequalities. And that in this range of possibilities the meanings of education are disputed between the regulations promoted by the State and the educational proposals developed and carried out in specific schools.

In the same vein, the study "Towards a participatory construction of education policy: the school success project in Valparaíso as an alternative proposal" by María Teresa Flórez Petour and José Miguel Olave Astorga presents a critical view of the current forms of educational policy in Chile. They refer to the results of an investigation into the national evaluation system of the SIMCE curriculum, where it is revealed as problematic in terms of participation for social justice. At the same time, they present an alternative case that evidences the participatory construction from the foundations for the construction of a largescale formative-oriented evaluation system, which stands out as a more democratic and, therefore, fairer form of evaluation.

The interview "Voluntary teacher work at higher education: precariousness of work conditions in Argentina, Brazil and Chile" by the authors Savana Diniz Gomes Melo and Suzana Gomes dos Santos analyze the educational reforms promoted in higher education in the last decades. They demonstrate that they seek to meet the requirements of capitalism, with an emphasis on training for work. The authors expose the precarious work experience in the three countries.

Although what has been reported so far shows with great concern the continuities of neoliberal, conservative policies that reveal the situation in the region with few structural changes, there are tensions in the educational system that give rise to alternative proposals, of disputes and struggles in different directions from the hegemonic.

This is how we present papers from four countries that propose different perspectives to reflect on aspects of educational policies and practices in the region. We find similarities and differences in each country, while the approaches presented invite us to get to know other realities and reflect on the particularities that concern us. As information to be able to locate in each country, at the end we present a comparative table of educational systems, especially basic education, their ages, names of the educational structure and the mandatory nature of each. 
Finally, the connection between the Brazilian National Evaluation System and the implementation of a Common National Curriculum Base is analyzed in the paper: "Largescale evaluation and Common National Curriculum Base (BNCC): dimensions of the policy of containment and release in Brazil", by Amanda Melchiotti Gonçalves, Dhyovana Guerra and Roberto Antônio Deitos. They present this connection as a dimension of the policy of containment and liberation in Brazil. To this end, they recover the discourse of International Organizations in maximizing the relevance of results and the work of business reformers in Brazilian education. The authors note that the implementation of the BNCC expresses the containment/restriction of access to scientific content, as well as the control and standardization sought in large-scale evaluations through the policy of releasing the so-called socio-emotional content as guidelines for learning.

The health emergency of this moment in the world once again brings to light the difficulties that we face in our countries, as unequal societies, which fight differently for measures of greater justice, we are currently suffering, some of the consequences of the themes dealt with in this Dossier.

Many of the consequences of such an exceptional and unpredictable stage can continue to be addressed in new studies, but the fact is that part of the devastating panorama of some sectors of the Latin American region finds elements of understanding in many of the articles that are presented here. We invite, then, to know, debate and exchange experiences about reality through the contributions on education and its alternatives, criticisms and theoretical reflections present in this Dossier and that they help in the construction of more democracy through education and social justice. 
Frame 1 - Educational system

\begin{tabular}{|c|c|c|c|c|}
\hline Countries & Educational Levels & Theoretical ages & Requirement & Duration \\
\hline Argentina & $\begin{array}{l}\text { Early Childhood Education } \\
\text { Elementary School } \\
\text { High School (common and } \\
\text { vocational education) } \\
\text { Higher Education (vocational or } \\
\text { university) }\end{array}$ & $\begin{array}{l}2-5 \\
6-12 \\
13-17 \text { Common } \\
13 / 18 \text { Vocational }\end{array}$ & $\begin{array}{l}4 \text { and 5- } \\
\text { Mandatory } \\
\text { Compulsory } \\
\text { Until the end of } \\
\text { High School - } \\
\text { Compulsory }\end{array}$ & $\begin{array}{l}0-5 \\
\text { 7- Elementary } \\
\text { School } \\
\text { 5-Common } \\
\text { 6-Vocational }\end{array}$ \\
\hline \multirow{3}{*}{ Brazil } & Forly Child hod Edurotion & 4 to 5 veorc old & Compulcory & 2 yeorc \\
\hline & Elementary School & 6 to 14 years old & Compulsory & 9 years \\
\hline & High School & 15 to 17 years old & Compulsory & 3 years \\
\hline \multirow[t]{4}{*}{ Chile } & $\begin{array}{l}\text { Early Childhood Education } \\
\text { (Nursery } 84 \text { days to } 2 \text { years old) } \\
\text { (Medium } 2 \text { to } 4 \text { years old) } \\
\text { Transition } 4 \text { to } 6 \text { years old) }\end{array}$ & $\begin{array}{l}84 \text { days to } 6 \text { years } \\
\text { old }\end{array}$ & Not Compulsory & Variable \\
\hline & Preschool & Until 5 years old & Compulsory & Variable \\
\hline & Elementary School & 5 to 13 years old & Compulsory & 8 years \\
\hline & High School & 13 to 18 years old & Compulsory & 4 years \\
\hline \multirow{4}{*}{ Mexico } & Preschool & 3 to 5 years old & Compulsory & 3 years \\
\hline & Elementary School & 6 to 12 years old & Compulsory & 7 years \\
\hline & High School & 12 to 15 years old & Compulsory & 4 years \\
\hline & $\begin{array}{l}\text { Higher Education } \\
\text { Bachelor/Preparatory }\end{array}$ & 15 to 18 years old & & 4 years \\
\hline
\end{tabular}

Source: elaborated by the authors

\section{How to reference this interview}

SANTOS, F.; MARTINEZ, S.; ZANARDINI, J. B. Political challenges for education and democracy in Latin America. Revista on line de Política e Gestão Educacional, Araraquara, v. $24, \quad$ n. esp. 1, p. 668-677, ago. 2020. e-ISSN:1519-9029. DOI: https://doi.org/10.22633/rpge.v24iesp1.13966

Submitted: $20 / 02 / 2020$

Revisões requeridas: 30/04/2020

Accepted: $28 / 06 / 2020$

Published on: 01/08/2020 